УДК 311.2

Е. А. Закревская

ФГБОУ ВО «РЭУ им. Г.В. Плеханова», Москва, e-mail: zakrevskaya.ea@rea.ru

\title{
Д. А. Максимов
}

ФГБОУ ВО «РЭУ им. Г.В. Плеханова», Москва, e-mail: maksimov.da@rea.ru

E. В. Швед

ФГБОУ ВО «РЭУ им. Г.В. Плеханова», Москва, e-mail: shved.ev@rea.ru

\section{СТАТИСТИЧЕСКИЙ АНАЛИЗ ПОКАЗАТЕЛЕЙ РАЗВИТИЯ РЕГИОНОВ РФ, ОТНОСЯЩИХСЯ К АРКТИЧЕСКОЙ ЗОНЕ}

Ключевые слова: арктическая зона, динамика, статистический анализ, метод многомерного ранжирования, суммарный ранг, тенденция.

Арктика - уникальный регион, в последние годы все сильнее привлекающий внимание государств северной части Тихого океана. Его возрастающий экономический, транспортно-логистический и экономический потенциал формирует прочную основу для международного взаимодействия, ученые и эксперты всего мира анализируют богатейший природный потенциал морей и недр, а также перспективы развития Северного морского пути. Современное видение Арктики через призму практического интереса отображается в тщательно проработанной стратегии развития и прослеживается в каждом мероприятии, направленном на освоение и управление регионом. Для решения ключевых социально-экономических проблем и повышения уровня эффективности развития были созданы новые условия для предпринимательской деятельности - Арктическая зона Российской Федерации, призванные оказывать поддержку инвесторам на всей территории АЗРФ и создавать для них максимально комфортные условия ведения бизнеса. Статистическое изучение показателей развития регионов РФ, относящихся к Арктической зоне основано на следующей системе показателей. В статье изучена динамика показателей развития регионов РФ, относящихся к Арктической зоне РФ с 2013 г. по 2018 г. Рассмотрены структура населения; выявлена основные тенденции изменения социальноэкономических показателей. Произведено ранжирование регионов, относящихся к Арктической зоне, по уровню социально-экономического развития и выявлено место региона в РФ.

\section{E. A. Zakrevskaya}

Plekhanov Russian University of Economics, Moscow, e-mail: zakrevskaya.ea@rea.ru

\section{A. Maksimov}

Plekhanov Russian University of Economics, Moscow, e-mail: maksimov.da@rea.ru

\section{E. V.Shved}

Plekhanov Russian University of Economics, Moscow, e-mail: shved.ev@rea.ru

\section{STATISTICAL ANALYSIS OF THE DEVELOPMENT INDICATORS OF THE REGIONS OF THE RUSSIAN FEDERATION RELATED TO THE ARCTIC ZONE}

Keywords: arctic zone, dynamics, statistical analysis, multidimensional ranking method, total rank, trend.

The Arctic is a unique region, which in recent years has increasingly attracted the attention of the states of the North Pacific. Its growing economic, transport, logistics and economic potential forms a solid basis for international cooperation, scientists and experts from all over the world analyze the rich natural potential of the seas and subsoil, as well as the prospects for the development of the Northern Sea Route. The modern vision of the Arctic through the prism of practical interest is reflected in a carefully elaborated development strategy and can be traced in every event aimed at the development and management of the region. In order to solve key socio-economic problems and increase the level of development efficiency, new conditions for entrepreneurial activity were created - the Arctic zone of the Russian Federation, designed to support investors throughout the territory of the Russian Arctic and create the most comfortable business conditions for them. The statistical study of the development indicators of the regions of the Russian Federation belonging to the Arctic zone is based on the following system of indicators: The article examines the dynamics of the development indicators of the regions of the Russian Federation belonging to the Arctic zone of the Russian Federation from 2013 to 2018. The structure of the population is considered; the main trends in socio-economic indicators are revealed. The regions belonging to the Arctic zone were ranked according to the level of socio-economic development and the place of the region in the Russian Federation was revealed. 


\section{Введение}

В последнее время интерес к развитию территорий, относящихся к Арктической зоне - региону, присоединяющемуся к Северному полюсу и включающему окраины материков Евразии и Северной Америки, Северный Ледовитый океан с островами, а также прилегающие части Атлантического и Тихого океанов сильно возрос. Площадь территорий Арктики составляет около 27 миллионов квадратных километров, что составляет 5,3\% от общей территории поверхности земли. И в силу своего расположения и климата, являются неизведанными.

Для всех государств, прилегающих к Арктике, она служит, безусловно, стратегически очень важной частью внутренней и внешней политики. К этим государствам помимо России относятся: Дания, Исландия, Канада, Норвегия, США, Финляндия, Швеция. Также в последнее время увеличивается заинтересованность с экономической точки зрения к этой зоне со стороны государств, не относящихся к Арктической зоне и не имеющих с ней общих границ, таких как: Великобритания, Германия, Индия, Испания, Италия, Корея, Китай, Нидерланды, Польша, Сингапур, Франция, Япония [2].

Основой экономики Арктического региона и входящих в него регионов является горнодобывающая отрасль. В регионах Российской Федерации, относящихся к Арктической зоне находятся 282 месторождения; из горючих полезных ископаемых добывают 13,2\% нефти (69,271 млн т в 2019 году); $87,4 \%$ горючих газов; $2 \%$ угля в общих объемах добычи по РФ; из металлических полезных ископаемых: 8,1\% железной руды; $43,9 \%$ хромовой руды; $100 \%$ титана и 46,2\% меди от общей добычи по РФ в целом. Из редких и драгоценных металлов в Арктической зоне РФ добывают 100\% Циркония; 88\% Галлия; 97,9\% Рубидия; 99\% апатитовых руд; 39,8\% алмазов; 7,4\% золота и 5,2\% серебра от общей добычи по РФ в целом. При этом $84 \%$ ресурсов находится на шельфе Северного Ледовитого океана и 16\% на сухопутной территории арктических государств. Ведущие места по добычи нефти занимают Ямало-Ненецкий автономный округ и Ненецкий автономный округ, где расположены наиболее крупные и уникальные месторождения. На шельфе Баренцева, Карского морей и моря Лаптевых находятся 8 месторождений нефти, запасы по ним составляют 118,254 млн т $(3,0 \%$ от запасов в целом по Арктической зоне), добыча в 2019 году составила 3,138 млн т (4,5\%). Основные нефтегазодобывающие предприятия, имеющие лицензии на месторождения шельфа Баренцева моря: ООО «Газпром нефть шельф», ЗАО «Арктикшельфнефтегаз», ООО «ЛУКОЙЛ-Коми», ПАО «НК «Роснефть». В Арктической зоне Российской Федерации (включая прилегающие акватории) расположены 204 месторождения горючих газов, что составляет 76,3\% от запасов по РФ, 16 898,309 млрд м³. Добыча свободного газа в пределах арктической зоны в 2019 году составила 607,517 млрд м ${ }^{3}-$ $87,4 \%$ от добычи в целом по РФ. Ведущее место по запасам и добыче свободного газа в Арктической зоне и в целом по Российской Федерации занимает Ямало-Ненецкий автономный округ. Основные нефтегазодобывающие предприятия, имеющие лицензии на месторождения шельфа Баренцева моря: ПАО «Газпром», ПАО «НК «Роснефть»; на месторождения шельфа Карского моря: ПАО «Газпром»; ООО «Газпром добыча Ямбург», ООО «РусГазАльянс», ООО «НОВАТЭК- Юрхаровнефтегаз», ООО «Арктик СПГ 3», ПАО «НК «Роснефть». Добыча свободного газа на шельфе Карского моря в 2019 году велась ООО «НОВАТЭКЮрхаровнефтегаз» $\left(16,506\right.$ млрд м $\left.{ }^{3}\right)$ и ОАО «Ямал СПГ» $\left(1,454\right.$ млрд м³ ${ }^{3}$. Запасы угля на территории Арктической зоны размещены крайне неравномерно, большая их часть (5 028,368 млн т - 70,2\% от запасов по всей арктической зоне) сосредоточена на территории городского округа Воркута в Республике Коми. Несмотря на то, что основные перспективы развития Арктической зоны РФ связаны с развитием минерально-сырьевой базы углеводородного сырья, немалое место в стратегии развития регионов Арктики отводится и развитию минерально-сырьевой базы твердых полезных ископаемых.

Цель работы - проведение статистического исследования показателей развития регионов РФ, относящихся к арктической зоне для дальнейшей оценки перспектив развития данного региона.

\section{Материалы и методы исследования}

Основными методами исследования в работе являлись первичный сбор и статистическая обработка разнотипных данных; анализ и представление собранной статистической информации; методы многомерного ранжирования и нахождение суммарного ранга. 


\section{Результаты исследования и их обсуждение}

В указе президента Российской Федерации от 2 мая 2014 года № 296 «О сухопутных территориях Арктической зоны Российской Федерации» [1] определены территории, относящиеся к суше Арктической зоны Российской Федерации (рисунок 1).

В Северо-Западном федеральном округе полностью относятся к Арктической зоне два субъекта Российской Федерации: Ненецкий автономный округ и Мурманская область; три региона частично относятся к Арктической зоне: Архангельская область - территории ее севера, включая Архангельск; Мезенский район; Новую Землю; Новодвинск; Онежский район; Приморский район; Северодвинск; Республика Коми и ее северные территории, включая городской округ Воркуту; Беломорский район; Лоухский район; Кемский район и север Республики Карелия.

В Уральском Федеральном округе один субъект Российской Федерации полностью относится к Арктической зоне: Ямало-Ненецкий автономный округ.

В Сибирском Федеральном округе один субъект Российской Федерации частично относится к Арктической зоне: север Красноярского края (Норильск; Таймырский район; Туруханский район).
В Дальневосточном Федеральном округе один субъект Российской Федерации полностью относится к Арктической зоне: Чукотский автономный округ; а один регион - частично: север Республики Саха Якутии (Абыйский улус; Аллаиховский улус; Анабарский национальный (долганоэвенкийский) улус; Булунский улус; Верхнеколымский улус; Верхоянский район; Жиганский национальный эвенкийский район; Момский район; Нижнеколымский район; Усть-Янский улус; Эвено-Бытантайский национальный улус; Оленёкский эвенкийский национальный район; Средне колымский улус).

Чрезвычайно выгодное географическое положение и изменяющиеся климатические условия обеспечивают непрерывное повышение экономического потенциала всего региона и Северного морского пути, в частности. Кратчайший морской путь между Тихим и Атлантическим океанами является транспортным коридором для транспортировки полезных ископаемых, нефтепродуктов, продовольствия и товаров жизнеобеспечения для народов Крайнего Севера.

Среди выгод можно отдельно выделить: сокращение сроков на транспортировку; сокращение расходов на оплату рейса; экономия топлива; отсутствие очереди; безопасность.

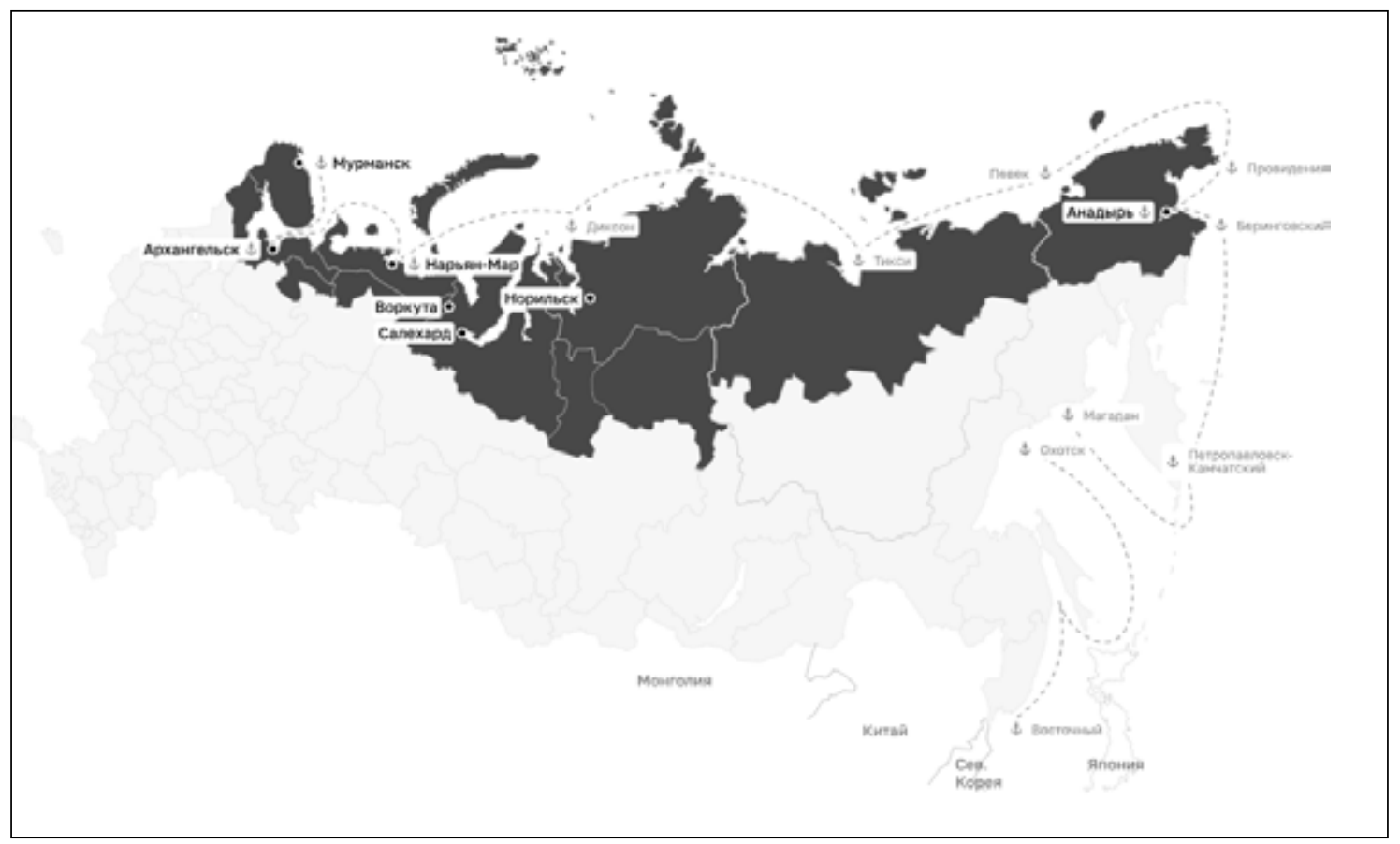

Рис. 1. Арктическая зона России [6] 
Согласно стратегии развития Арктики, объем грузопотока многократно вырастет благодаря развитию нефте- и газодобывающих проектов. Совместно с этим в нашей стране ведутся работы по улучшению инфраструктурного обеспечения морских портов, логистических комплексов и перевалочных пунктов.

Согласно Международному Арктическому форуму [7] выделены следующие приоритетные направления работы в данной зоне: ктики;

1. Сохранение экологии и природы Ар-

2. Подготовка кадров для обеспечения развития Арктики;

3. Развитие энергетического потенциала Арктики;

4. Развитие туристического потенциала Арктики;

5. Создание и модернизация транспортной инфраструктуры Арктики;

6. Развитие международного и межрегионального сотрудничества в Арктике;

7. Реализация международных инвестиционных проектов;

8. Эффективные подходы к территориальному развитию региона;

9. Наука и технологии на службе Арктики.

Структура населения в регионах РФ, относящихся к арктической зоне.
Всего в регионах, относящихся к Арктической зоне РФ, проживало в 2018 году 7844,8 тысяч человек, из них 3709 тысяч человек - мужчины, а 4135,8 тысяч человек - женщины; в 2019 году - 7816,4 тысяч человек, из них 3696,8 тысяч - мужчины, а 4119,6 тысяч - женщины; что составляет $5,3 \%$ от общего населения Российской Федерации (таблица 1, 2, 3). Из них городское население составляет $78 \%$, а сельское $-22 \%$. Также следует отметить, что естественный прирост населения в отличие от всей России в целом, где происходит убыль населения, наблюдается в следующих регионах, относящихся к арктической зоне: Ненецкий $\mathrm{AO}(6,6 \%$ в 2017 году и 7,1\% в 2018 году), Ямало-Ненецкий автономный округ $(9,1 \%$ в 2017 году и 8,7\% в 2018 году), Республика Саха (Якутия) (6,4\% в 2017 году и 5,9\% в 2018 году), Чукотский АО (3,7\% в 2017 году и $1,6 \%$ в 2018 году) (рисунок 2).

Экономические показатели развития регионов РФ, относящихся к арктической зоне.

В регионах, относящихся к арктической зоне (таблица 4) сосредоточено примерно $5 \%$ от общей численности рабочей силы по всей России и примерно 6,6\% всех безработных. Уровень безработицы в данных регионах составил $6,3 \%$ в 2017 году и $6 \%$ в 2018 году, что превышает уровень безработицы в Российской Федерации в эти годы.

Таблица 1

Численность населения (оценка на 1 января; тысяч человек)

\begin{tabular}{|l|c|c|c|c|}
\hline & $\mathbf{2 0 1 8}$ & $\mathbf{2 0 1 9}$ & $\begin{array}{c}\text { Городское население, } \\
\mathbf{\% , 2 0 1 9}\end{array}$ & $\begin{array}{c}\text { Сельское население, } \\
\text { \%, 2019 }\end{array}$ \\
\hline Всего в регионах Арктики & 7844,8 & 7816,4 & 78,33 & 21,67 \\
\hline \% от общего населения РФ & 5,3 & 5,3 & & \\
\hline
\end{tabular}

Таблица 2

Структура населения регионов Арктики по возрастным группам

\begin{tabular}{|c|c|c|c|c|c|c|c|c|c|c|c|c|}
\hline & \multicolumn{6}{|c|}{$\begin{array}{c}\text { Удельный вес отдельных возрастных } \\
\text { групп населения в общей численности } \\
\text { населения, процентов }\end{array}$} & \multicolumn{6}{|c|}{$\begin{array}{c}\text { На } 1000 \text { человек трудоспособного возраста } \\
\text { приходится лиц нетрудоспособных } \\
\text { возрастов }\end{array}$} \\
\hline & \multirow{2}{*}{\multicolumn{2}{|c|}{$\begin{array}{c}\text { моложе тру- } \\
\text { доспособного }\end{array}$}} & \multirow{2}{*}{\multicolumn{2}{|c|}{$\begin{array}{c}\text { трудоспособ- } \\
\text { ном }\end{array}$}} & \multirow{2}{*}{\multicolumn{2}{|c|}{$\begin{array}{l}\text { старше тру- } \\
\text { доспособного }\end{array}$}} & \multirow{2}{*}{\multicolumn{2}{|c|}{ всего }} & \multicolumn{4}{|c|}{ В том числе } \\
\hline & & & & & & & & & $\begin{array}{l}\text { моло } \\
\text { доспо }\end{array}$ & $\begin{array}{l}\text { е тру- } \\
\text { бного }\end{array}$ & $\begin{array}{l}\text { стари } \\
\text { доспос }\end{array}$ & $\begin{array}{l}\text { е тру- } \\
\text { бного }\end{array}$ \\
\hline & 2018 & 2019 & 2018 & 2019 & 2018 & 2019 & 2018 & 2019 & 2018 & 2019 & 2018 & 2019 \\
\hline $\begin{array}{l}\text { Среднее } \\
\text { по всем } \\
\text { регионам } \\
\text { Арктики }\end{array}$ & 21,4 & 21,5 & 58,2 & 57,6 & 20,4 & 20,9 & 722,2 & 740,1 & 367,9 & 371,8 & 354,3 & 368,3 \\
\hline
\end{tabular}


Ожидаемая продолжительность лет при рождении (число лет)

\begin{tabular}{|l|c|c|c|c|}
\hline & \multicolumn{2}{|c|}{ мужчины } & \multicolumn{2}{c|}{ женщины } \\
\hline & $\mathbf{2 0 1 7}$ & $\mathbf{2 0 1 8}$ & $\mathbf{2 0 1 7}$ & $\mathbf{2 0 1 8}$ \\
\hline РФ & 67,51 & 67,75 & 77,64 & 77,82 \\
\hline Среднее по всем регионам Арктики & 65,50 & 65,51 & 76,29 & 76,23 \\
\hline
\end{tabular}

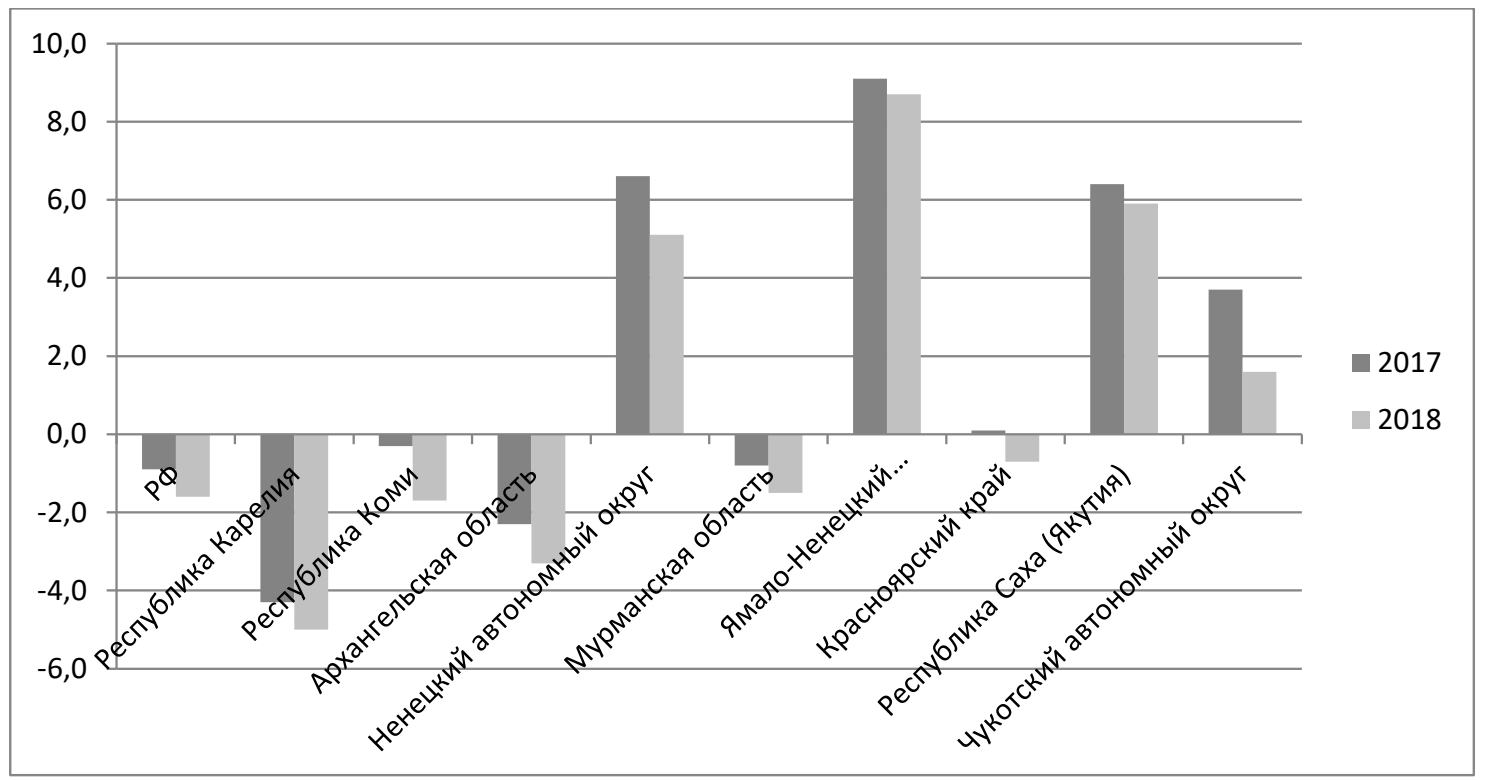

Рис. 2. Естественный прирост / убыль населения в регионах Арктики в 2017 и 2018 годах, на 1000 человек

Таблица 4

Численность рабочей силы (в среднем за год)

\begin{tabular}{|c|c|c|c|c|c|c|c|c|}
\hline & \multirow{2}{*}{\multicolumn{2}{|c|}{$\begin{array}{c}\text { Численность } \\
\text { рабочей силы, } \\
\text { тыс. человек }\end{array}$}} & \multicolumn{4}{|c|}{ в том числе } & \multirow{2}{*}{\multicolumn{2}{|c|}{$\begin{array}{c}\text { Уровень } \\
\text { безработицы, } \\
\text { в процентах }\end{array}$}} \\
\hline & & & \multicolumn{2}{|c|}{ занятые } & \multicolumn{2}{|c|}{ безработные } & & \\
\hline & 2017 & 2018 & 2017 & 2018 & 2017 & 2018 & 2017 & 2018 \\
\hline Суммарно по регионам Арктики & 4157,8 & 4114,2 & 3893 & 3872,1 & 264,7 & 242,1 & 6,3 & 6,0 \\
\hline \% от РФ в целом & 5,5 & 5,4 & 5,4 & 5,3 & 6,7 & 6,6 & & \\
\hline $\begin{array}{l}\text { Превышение показателя относи- } \\
\text { тельно РФ }\end{array}$ & & & & & & & 1,1 & 1,2 \\
\hline
\end{tabular}

По уровню заработной платы регионы Арктики существенно превосходят остальные регионы РФ. Так, заработная плата педагогических работников; врачей; медицинский персонал; социальных работников более чем на $50 \%$ превышает средние заработные платы по РФ в среднем (таблица 5,6 , рисунок 3 ).

Однако денежные доходы населения нельзя рассматривать от уровня цен в реги- оне, что особенно существенно для северных, труднодоступных регионов. В таблице 7 рассмотрено превышения (если число со знаком «+») либо снижение (если число со знаком «-») показателя покупательной способности денежных доходов регионов, относящихся к арктической зоне относительно средних значений по Российской Федерации. 
Таблица 5

Уровень средней заработной платы отдельных категорий работников социальной сферы и науки (рублей)

\begin{tabular}{|c|c|c|c|}
\hline & $\begin{array}{l}\text { Российская } \\
\text { Федерация }\end{array}$ & $\begin{array}{c}\text { Среднее } \\
\text { по регионам } \\
\text { Арктики } \\
\end{array}$ & $\begin{array}{l}\text { Превышение } \\
\text { над РФ, \% }\end{array}$ \\
\hline $\begin{array}{l}\text { Педагогические работники дошкольных образовательных } \\
\text { организаций }\end{array}$ & 31670 & 50110 & 58 \\
\hline $\begin{array}{l}\text { Педагогические работники образовательных организаций } \\
\text { общего образования }\end{array}$ & 38419 & 59359 & 55 \\
\hline $\begin{array}{l}\text { Педагогические работники организаций дополнительного } \\
\text { образования детей }\end{array}$ & 35954 & 61319 & 71 \\
\hline $\begin{array}{l}\text { Преподаватели и мастера производственного обучения } \\
\text { образовательных организаций начального и среднего про- } \\
\text { фессионального образования }\end{array}$ & 36536 & 61965 & 70 \\
\hline $\begin{array}{l}\text { Преподаватели образовательных учреждений высшего } \\
\text { профессионального образования }\end{array}$ & 82486 & 91233 & 11 \\
\hline $\begin{array}{l}\text { Врачи и работники медицинских организаций, имеющие } \\
\text { высшее медицинское образование (фармацевтическое) } \\
\text { или иное высшее образование, предоставляющие меди- } \\
\text { цинские услуги (обеспечивающие предоставление меди- } \\
\text { цинских услуг) }\end{array}$ & 75007 & 116585 & 55 \\
\hline $\begin{array}{l}\text { Средний медицинский (фармацевтический) персонал } \\
\text { (персонал, обеспечивающий условия для предоставления } \\
\text { медицинских услуг) }\end{array}$ & 36965 & 58677 & 59 \\
\hline $\begin{array}{l}\text { Младший медицинский персонал (персонал, обеспечива- } \\
\text { ющий условия для предоставления медицинских услуг) }\end{array}$ & 34254 & 57569 & 68 \\
\hline Социальные работники & 33113 & 52652 & 59 \\
\hline Работники учреждений культуры & 38971 & 58847 & 51 \\
\hline Научные сотрудники & 100081 & 106338 & 6 \\
\hline $\begin{array}{l}\text { Педагогические работники образовательных, медицин- } \\
\text { ских организаций или организаций, оказывающих соци- } \\
\text { альные услуги детям-сиротам и детям, оставшимся без } \\
\text { попечения родителей }\end{array}$ & 36965 & 47976 & 30 \\
\hline
\end{tabular}

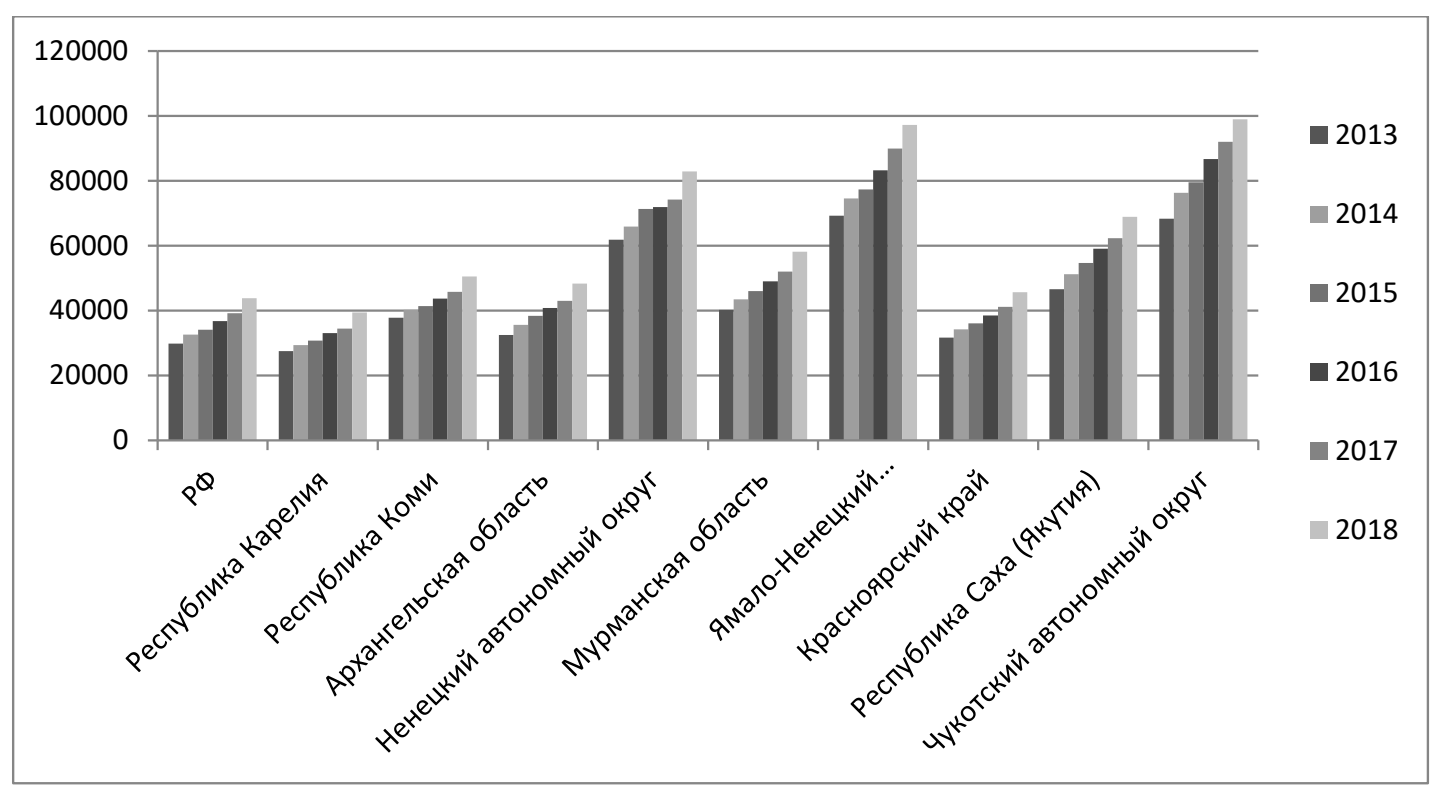

Рис. 3. Динамика среднемесячной номинальной заработной платы в регионах, относящиххя к Арктической зоне РФ в сравнении с РФ в ичелом, руб. 
Отношение средней заработной платы отдельных категорий работников социальной сферы и науки к среднемесячному доходу от трудовой деятельности в регионах Арктики (процентов) в 2018 году

\begin{tabular}{|c|c|c|c|}
\hline & $\begin{array}{l}\text { Российская } \\
\text { Федерация }\end{array}$ & $\begin{array}{c}\text { Среднее по } \\
\text { регионам } \\
\text { Арктики }\end{array}$ & $\begin{array}{c}\text { Превышение } \\
\text { средних показателей } \\
\text { регионов Арктики } \\
\text { над РФ в целом } \\
\end{array}$ \\
\hline $\begin{array}{l}\text { Педагогические работники дошкольных образова- } \\
\text { тельных организаций }\end{array}$ & 92 & 99,2 & 7,2 \\
\hline $\begin{array}{l}\text { Педагогические работники образовательных орга- } \\
\text { низаций общего образования }\end{array}$ & 101,4 & 100,7 & $-0,7$ \\
\hline $\begin{array}{l}\text { Педагогические работники организаций дополни- } \\
\text { тельного образования детей }\end{array}$ & 95,8 & 100,7 & 4,9 \\
\hline $\begin{array}{l}\text { Преподаватели и мастера производственного обу- } \\
\text { чения образовательных организаций начального и } \\
\text { среднего профессионального образования }\end{array}$ & 96,4 & 104,2 & 7,8 \\
\hline $\begin{array}{l}\text { Преподаватели образовательных учреждений выс- } \\
\text { шего профессионального образования }\end{array}$ & 220 & 201 & $-19,1$ \\
\hline $\begin{array}{l}\text { Врачи и работники медицинских организаций, } \\
\text { имеющие высшее медицинское образование (фар- } \\
\text { мацевтическое) или иное высшее образование, } \\
\text { предоставляющие медицинские услуги (обеспечи- } \\
\text { вающие предоставление медицинских услуг) }\end{array}$ & 198 & 197 & -1 \\
\hline $\begin{array}{l}\text { Средний медицинский (фармацевтический) пер- } \\
\text { сонал (персонал, обеспечивающий условия для } \\
\text { предоставления медицинских услуг) }\end{array}$ & 97,6 & 99,9 & 2,3 \\
\hline $\begin{array}{l}\text { Младший медицинский персонал (персонал, обе- } \\
\text { спечивающий условия для предоставления меди- } \\
\text { цинских услуг) }\end{array}$ & 90,4 & 97,6 & 7,2 \\
\hline Социальные работники & 87,4 & 99,7 & 12,3 \\
\hline Работники учреждений культуры & 102,9 & 100 & $-2,9$ \\
\hline Научные сотрудники & 260 & 204,1 & $-55,9$ \\
\hline $\begin{array}{l}\text { Педагогические работники образовательных, ме- } \\
\text { дицинских организаций или организаций, оказы- } \\
\text { вающих социальные услуги детям-сиротам и де- } \\
\text { тям, оставшимся без попечения родителей }\end{array}$ & 97,6 & 101 & 3,4 \\
\hline
\end{tabular}

В Ненецком автономном округе; Мурманской области и Ямало-Ненецком автономном округе покупательная способность существенно выше, чем в среднем по РФ. В республике Карелия, республики Коми, Архангельской области, Красноярском крае - ниже; республике Саха и Чукотском автономном округе покупательная способность денежных доходов по определенным продуктам питания выше, а по другим - ниже чем по Российской Федерации в среднем.

Валовый региональный продукт на душу населения существенно выше в Ненецком и Ямало-Ненецком автономных округах (рисунок 4), чем по России в целом, что объясняется тем, что они занимают ведущие места по добычи нефти и газа.
Проанализируем показатели регионов Арктики по достижению национальных проектов развития регионов в 2019 г. (таблица 8). Среди положительных факторов, следует отметить уровень смертности населения старше трудоспособного возраста ниже, чем по РФ в целом; а уровень рождаемости, занятости женщин с детьми - выше. Среди негативных факторов можно выделить превышение показателя смертности людей трудоспособного возраста над среднем значением по РФ в целом, при этом смертность от наиболее значимых болезней (системы кровообращения и новообразования) ниже, чем по РФ. Также среди негативных факторов развития данных регионов можно отметить низкую долю исследователей до 39 лет и нехватку внутренних затрат на исследования. 
Превышение (снижение) показателя покупательной способности для продуктов питания

\begin{tabular}{|c|c|c|c|c|c|c|c|c|c|}
\hline & & $\begin{array}{r}\text { ревын } \\
\text { ден }\end{array}$ & $\begin{array}{l}\text { ние (c } \\
\text { қных д }\end{array}$ & $\begin{array}{l}\text { кение) г } \\
\text { дов для }\end{array}$ & $\begin{array}{l}\text { оказате } \\
\text { регион }\end{array}$ & $\begin{array}{l}\text { гя покупа } \\
\text { относите }\end{array}$ & $\begin{array}{l}\text { ельной } \\
\text { ьно РФ }\end{array}$ & $\begin{array}{l}\text { пособно } \\
\text { в целом }\end{array}$ & \\
\hline & 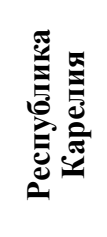 & 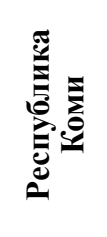 & 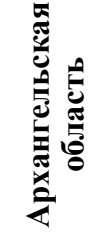 & 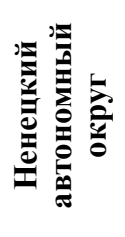 & 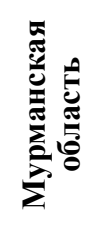 & 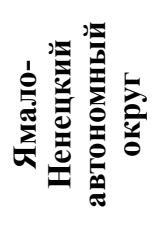 & 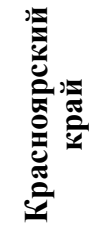 & 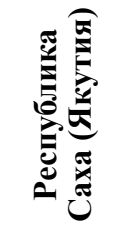 & 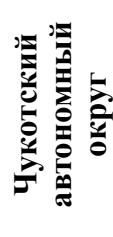 \\
\hline $\begin{array}{l}\text { Говядина (кроме } \\
\text { бескостного мяса) }\end{array}$ & $-27,7$ & $-14,4$ & $-9,8$ & 119,2 & 5,2 & 101,1 & $-6,9$ & $-3,9$ & 81,1 \\
\hline $\begin{array}{l}\text { Свинина (кроме } \\
\text { бескостного мяса) }\end{array}$ & -18 & $-14,6$ & $-10,2$ & 90,3 & 17,5 & 100,4 & -23 & $-7,7$ & 22,9 \\
\hline $\begin{array}{l}\text { Куры охлажденные } \\
\text { и мороженые }\end{array}$ & $-4,1$ & $-11,6$ & $-27,3$ & 125,5 & 47,2 & 151,5 & $-36,8$ & $-28,9$ & 20,6 \\
\hline $\begin{array}{l}\text { Рыба замороженная } \\
\text { (кроме лососевых } \\
\text { пород и рыбного } \\
\text { филе) }\end{array}$ & $-13,7$ & $-6,1$ & $-12,1$ & 117,6 & 33,6 & 112,3 & $-23,3$ & 22,4 & 119,2 \\
\hline Масло сливочное & $-15,2$ & $-5,1$ & $-9,8$ & 45 & $-0,9$ & 62,2 & $-6,9$ & 16,7 & 27,7 \\
\hline Масло подсолнечное & $-69,7$ & $-26,2$ & $-20,9$ & 261,1 & 23,4 & 307,8 & $-36,8$ & $-2,9$ & 108,1 \\
\hline Молоко питьевое, л & $-108,7$ & $-60,3$ & -84 & 300,4 & 40,7 & 338,5 & $-77,8$ & 12,2 & 113,4 \\
\hline Творог & $-29,3$ & 6,9 & $-1,1$ & 179,1 & 5,7 & 62,4 & $-30,4$ & $-31,4$ & 48,2 \\
\hline $\begin{array}{l}\text { Сыры сычужные } \\
\text { твердые и мягкие }\end{array}$ & $-3,1$ & 3 & $-8,3$ & 61,2 & 15,7 & 76,8 & $-6,1$ & 2,7 & 11,8 \\
\hline Яйца куриные, шт. & -952 & -127 & 87 & 4788 & 1150 & 4280 & -543 & -804 & -1877 \\
\hline Сахар-песок & $-108,1$ & $-19,3$ & 22,9 & 358,8 & 164,2 & 300,1 & $-186,4$ & $-159,5$ & $-66,1$ \\
\hline $\begin{array}{l}\text { Соль повареная } \\
\text { пищевая }\end{array}$ & $-419,5$ & $-712,5$ & -385 & $-521,5$ & 29,4 & 560,2 & $-803,1$ & $-1254,1$ & -1493 \\
\hline $\begin{array}{l}\text { Чай черный байхо- } \\
\text { вый (весовой) }\end{array}$ & $-10,5$ & $-0,2$ & -5 & 51,5 & 5,3 & 39 & 1,4 & 6 & 8,7 \\
\hline Мука пшеничная & $-384,6$ & $-122,6$ & $-141,9$ & 101,1 & $-44,9$ & 471,3 & $-85,9$ & $-147,5$ & -195 \\
\hline Цитрусовые & -19 & $-25,8$ & $-9,5$ & 136,6 & 86,9 & 212,9 & $-67,5$ & $-114,5$ & $-105,2$ \\
\hline $\begin{array}{l}\text { Хлеб из ржаной } \\
\text { муки и из смеси } \\
\text { муки ржаной и } \\
\text { пшеничной }\end{array}$ & $-288,1$ & $-75,9$ & $-161,7$ & 848,8 & $-117,5$ & 446,1 & $-261,4$ & -176 & -185 \\
\hline Крупы & $-293,6$ & -105 & -84 & 114,5 & $-110,5$ & 321,7 & $-160,3$ & $-152,9$ & -32 \\
\hline $\begin{array}{l}\text { Макаронные } \\
\text { изделия }\end{array}$ & $-174,2$ & $-132,6$ & $-164,3$ & 61,1 & $-124,7$ & 126 & $-96,2$ & -139 & $-68,8$ \\
\hline Картофель & $-89,2$ & $-182,1$ & $-152,8$ & 251,6 & 90,4 & 1022,7 & $-213,8$ & $-488,1$ & $-442,8$ \\
\hline $\begin{array}{l}\text { Капуста белокочан- } \\
\text { ная свежая }\end{array}$ & $-178,5$ & $-246,2$ & -266 & 89,5 & 109,4 & 963,7 & $-82,9$ & $-615,1$ & $-935,4$ \\
\hline Лук репчатый & $-146,6$ & $-244,9$ & $-238,9$ & 217,6 & 119,5 & 976 & $-158,4$ & $-511,4$ & $-720,8$ \\
\hline Свекла столовая & $-28,8$ & $-132,1$ & $-229,2$ & 265,1 & 159,7 & 1156,1 & $-152,2$ & $-453,3$ & $-679,4$ \\
\hline Морковь & $-170,9$ & $-133,5$ & $-122,9$ & 408,8 & 120,4 & 1261,4 & $-187,5$ & $-407,2$ & $-488,9$ \\
\hline
\end{tabular}




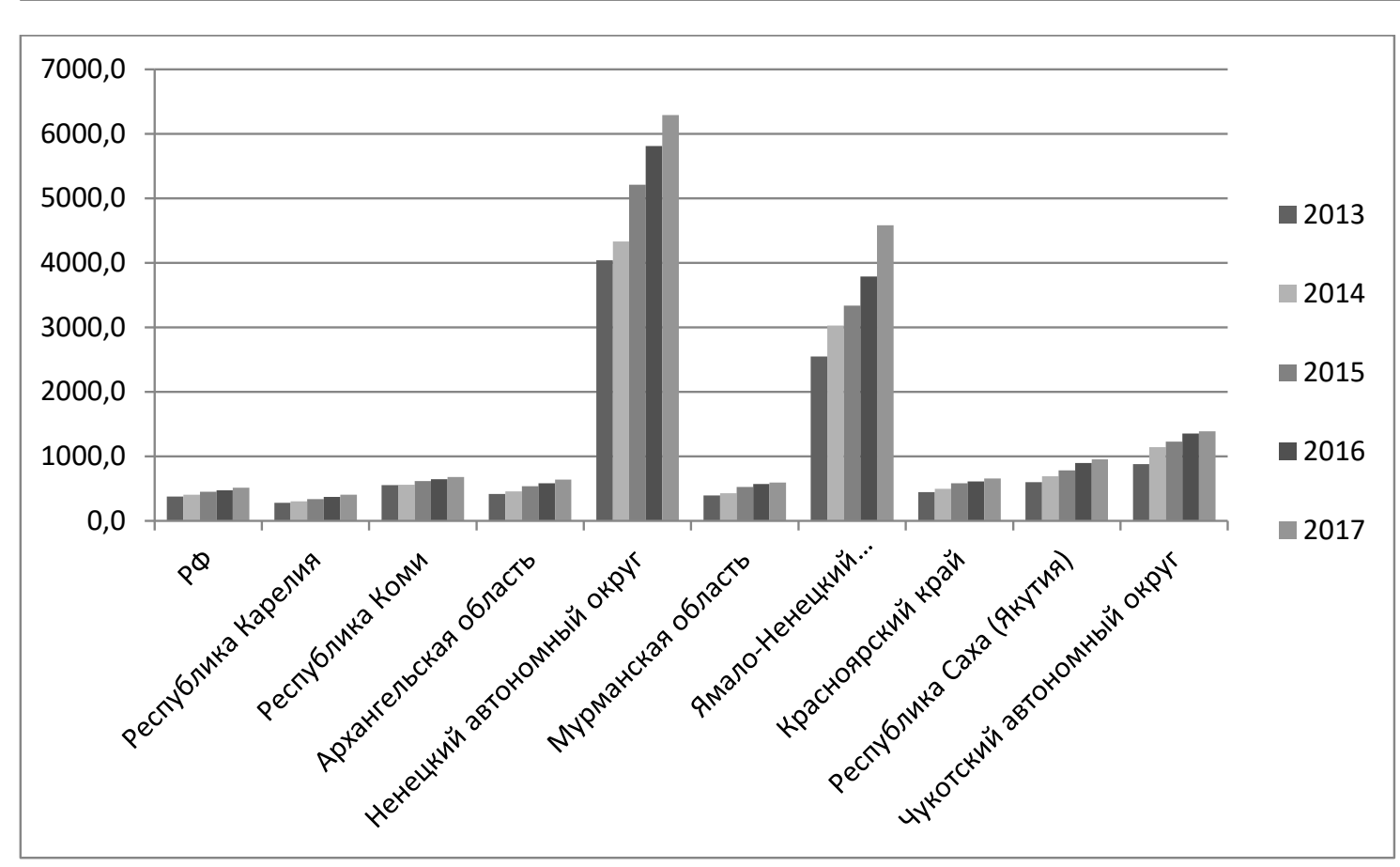

Рис. 4. Динамика ВРП на душу населения в регионах,

относящихся к Арктической зоне РФ в сравнении с РФ в иелом, тыс. руб.

Таблица 8

Показатели достижения национальных проектов развития регионов, относящихся к Арктической зоне РФ в 2019 году

\begin{tabular}{|l|c|c|c|}
\hline & $\begin{array}{c}\text { Российская } \\
\text { Федерация }\end{array}$ & $\begin{array}{c}\text { Среднее } \\
\text { пегионам } \\
\text { Арктики }\end{array}$ & $\begin{array}{c}\text { Превышение } \\
\text { над РФ } \\
\text { в целом }\end{array}$ \\
\hline Ожидаемая продолжительность жизни людей 55 лет, лет & 23,75 & 22,88 & $-0,87$ \\
\hline Ожидаемая продолжительность здоровой жизни, лет & 58,9 & 53,7 & $-5,2$ \\
\hline $\begin{array}{l}\text { Смертность населения старше трудоспособного возраста } \\
\text { на 100000 человек населения соответствующего возраста }\end{array}$ & 3667,9 & 3165,51 & $-502,39$ \\
\hline $\begin{array}{l}\text { Суммарный коэффициент рождаемости, число детей на } \\
\text { женщину }\end{array}$ & 1,504 & 1,66 & 0,15 \\
\hline Доля граждан, ведущих здоровый образ жизни, процентов & 9,1 & 8,21 & $-0,89$ \\
\hline $\begin{array}{l}\text { Уровень занятости женщин, имеющих детей дошкольного } \\
\text { возраста }\end{array}$ & 67 & 74,72 & 7,72 \\
\hline $\begin{array}{l}\text { Смертность населения трудоспособного возраста, на } \\
\text { 100000 человек }\end{array}$ & 470 & 563,94 & 93,94 \\
\hline $\begin{array}{l}\text { Смертность от болезней системы кровообращения, на } \\
\text { 100000 человек }\end{array}$ & 573,2 & 496,97 & $-76,23$ \\
\hline Смертность от новообразований на 100000 человек & 203,5 & 183,43 & $-20,07$ \\
\hline $\begin{array}{l}\text { Младенческая смертность детей дот года на 1000 ро- } \\
\text { дившихся }\end{array}$ & 4,9 & 5,46 & 0,56 \\
\hline Объем жилищного строительства, млн м² общей площади & 82 & 0,36 & $-81,64$ \\
\hline Средняя стоимость 1 м² жилья, тыс. руб. & 63,5 & 62,03 & $-1,47$ \\
\hline Доля исследователей до 39 лет, \% & 44,2 & 42,34 & $-1,86$ \\
\hline Внутренние затраты на исследования, млрд руб. & 1134,8 & 4,73 & $-1130,08$ \\
\hline Доля домохозяйств, имеющих доступ к Интернету, \% & 73,6 & 74,41 & 0,81 \\
\hline
\end{tabular}




\section{Заключение}

В заключении следует отметить, что регионы Российской Федерации, относящиеся к Арктической зоне, занимают достаточно высокое место по социально-экономическому развитию среди всех регионов (рисунок 5, таблица 9).

Анализ проводился методом многомерного ранжирования по следующим показателям: численность населения региона, приходящихся на одну тысячу квадратных километров; площадь территории региона; валовый региональный продукт на душу населения; поступление налогов и сборов на душу населения; стоимость основных фондов на душу населения; инвестиции на душу населения; оборот розничной торговли на душу населения; уровень занятости населения; денежные доходы населения; уровень безработицы; объем отгруженных товаров собственного производства, выполненных работ и услуг собственными силами по видам экономической деятельности таким как: добыча полезных ископаемых, обрабатывающие производства, обеспечение электрической энергией, газом и паром, кондиционирование воздуха водоснабжение, водоотведение, организация сбора и утилизации отходов, деятельность по ликвидации загрязнений; продукция сельского хозяйства; удельный вес автомобильных дорог с твердым покрытием; ввод в эксплуатацию жилых домов на 1000 человек населения региона; число персональных компьютеров на 100 работников; заработная плата работников организаций; общая площадь жилых помещений на одного человека; число собственных легковых автомобилей на 10000 человек; численность студентов, обучающихся по программам высшего образования на 10000 человек. Далее проводилась сверткой к единому показателю в виде суммарного ранга, для определения положения региона в РФ в целом.

Красноярский край занимает 10 место по социально-экономическому развитию среди всех регионов РФ, Ямало-Ненецкий $\mathrm{AO}$ - 19; Республика Саха (Якутия) - 26; Республика Коми - 28; Мурманская область 30 ; архангельская область - 43; Ненецкий $\mathrm{AO}$ - 45; Республика Карелия - 46; Чукотский $\mathrm{AO}-48$.

Таблица 9

Показатели социально-экономического развития регионов, относящихся к Арктической зоне РФ в 2019 году

\begin{tabular}{|l|c|c|c|}
\hline & $\begin{array}{c}\text { Российская } \\
\text { Федерация }\end{array}$ & $\begin{array}{c}\text { Среднее } \\
\text { по регионам } \\
\text { Арктики }\end{array}$ & $\begin{array}{c}\text { Превышение показателя } \\
\text { по регионам Арктики } \\
\text { над РФ в целом }\end{array}$ \\
\hline $\begin{array}{l}\text { Численность человек (тыс.чел.), приходя- } \\
\text { щихся на 1 тыс. км }\end{array}$ & 8,57 & 1,74 & $-6,83$ \\
\hline \% занятых в общей численности насления & 48,43 & 55,69 & 7,26 \\
\hline $\begin{array}{l}\text { Денежные доходы населения на 1 душу } \\
\text { населения }\end{array}$ & 35247 & 52114,67 & 16867,67 \\
\hline $\begin{array}{l}\text { Потребительские расходы на душу насе- } \\
\text { ления }\end{array}$ & 28470 & 30226,33 & 1756,33 \\
\hline $\begin{array}{l}\text { Заработная плата работников организаций, } \\
\text { рублей }\end{array}$ & 47867 & 69890 & 22023 \\
\hline ВРП на душу населения, млн руб./чел. & 579,06 & 2048,74 & 4669,68 \\
\hline $\begin{array}{l}\text { Инвестиции на душу населения, } \\
\text { млн руб/чел. }\end{array}$ & 131,65 & 594,43 & 5637,43 \\
\hline $\begin{array}{l}\text { Стоимость основных фондов на душу на- } \\
\text { селения, млн руб/чел. }\end{array}$ & 2383,2 & 8020,63 & $-4,3$ \\
\hline $\begin{array}{l}\text { Ввод в эксплуатацию жилых домов на об- } \\
\text { щую площадь региона; тыс. м на 1 тыс. км }\end{array}$ & 4,7907 & 0,4877 & 226,34 \\
\hline $\begin{array}{l}\text { Оборот розничной торговли на душу на- } \\
\text { селения, млн руб/чел. }\end{array}$ & 0,23 & 226,57 & 278,71 \\
\hline $\begin{array}{l}\text { Финансовый результат деятельности орга- } \\
\text { низаций на душу населения, млн руб/чел. }\end{array}$ & 113,34 & 392,05 & \\
\hline
\end{tabular}




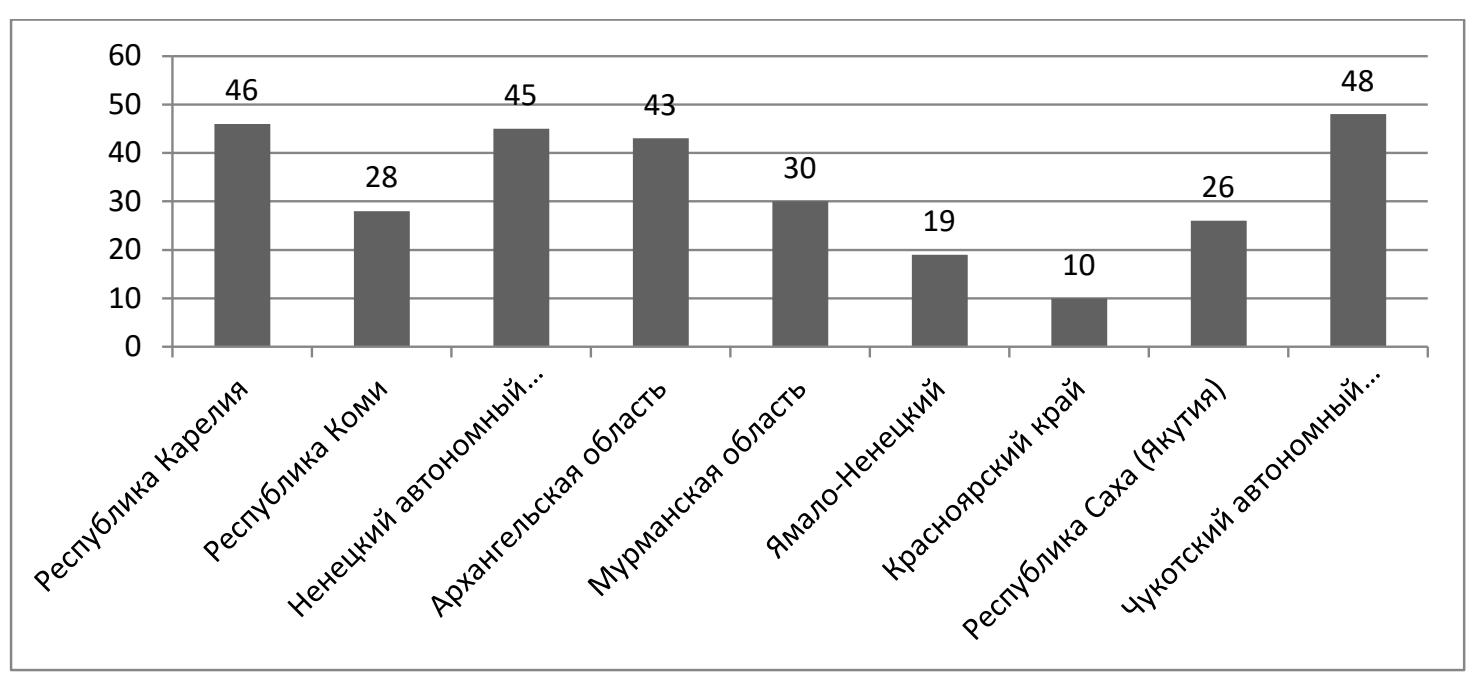

Рис. 5. Ранжирование регионов, относящихся к Арктической зоне по сочиально-экономическим показателям среди всех субъектов РФ в 2019 году

Следует также отметить, что по многим показателям регионы, относящиеся к Арктической зоне занимают первые места среди всех регионов РФ, так Ненецкий АО лидирует по ВРП на душу населения и инвестициям на душу населения; Чукотский АО находится на первом месте среди всех регионов по денежным доходам, заработной плате и процента занятых; а Ямало-Ненецкий округ находится на втором месте по этим показателям. Республика Саха (Якутия) имеет самую большую площадь территории в РФ. Однако по уровню безработицы; числу персональных компьютеров; числу собственных легковых автомобилей; численности студентов; общей площади жилых помеще- ний на человека; удельному весу автомобильных дорог; продукции сельского хозяйства; регионы, относящиеся к Арктической зоне занимают последние места среди всех регионов Российской Федерации. Несмотря на высокие доходы населения, большой процент обрабатывающих производств; высокую заработную плату, инвестиции и ВРП на душу населения уровень жизни в данных регионах надо рассматривать относительно их расположения, что накладывает трудности проживания в данных регионах; плохую обеспеченность жильем; недостаточную цифровизацию регионов. Это необходимо учитывать в перспективах развития этого уникального региона.

Библиографический список

1. Указ Президента Российской Федерации от 02.05.2014 г. № 296. О сухопутных территориях Арктической зоны Российской Федерации. URL: http://www.kremlin.ru/acts/bank/38377 (дата обращения 15.12.2021).

2. Быковский В. К. Арктическая зона российской федерации: правовой режим развития, обеспечения безопасности, охраны природы, защиты национальных интересов // Международное сотрудничество евразийских государств: политика, экономика, право. 2019. № 1. С. 88-96.

3. Емельянцев В. П. Сохранение и устойчивое развитие Арктики. Правовые аспекты. М.: Ин-т законодательства и сравн. правоведения при Правительстве Российской Федерации; Салехард: Юриспруденция, 2014.

4. Инвестировать в Север: зачем ярославским предпринимателям становиться резидентами Арктической зоны. URL: https://76.ru/text/business/2021/08/30/70107566/ (дата обращения: 15.12.2021).

5. Федеральная служба государственной статистики. Регионы России. Социально-экономические показатели - 2020 г. URL: https://gks.ru/bgd/regl/b20_14p/Main.htm (дата обращения: 10.10.2021).

6. Об Арктической зоне РФ. URL: https://erdc.ru/about-azrf/ (дата обращения: 10.10.2021).

7. Международный арктический форум. URL: https:// www.forumarctica.ru (дата обращения: 10.10.2021). 